\title{
Trust as e Relationship Treated by Common Law Legal Systems and as a Relationship Treated by Civil Law Legal Systems. Things in Common and Comparison between the Two Systems
}

\author{
By Nertila Sulçe ${ }^{1}$
}

\begin{abstract}
Inheritance relationships are born when the ownership was born and will exist as the property's right herself. Inheritance is an ancient institution recognized by the Roman law in the Twelve Tables (303 BC) in which the testamentary right was given priority.Roman law had a well-developed concept of the trust (fideicommissum) in terms of "testamentary trusts" created by wills but never developed the concept of the inter vivos (living) trusts which apply while the creator lives. Trusts have existed since Roman times and have become one of the most important innovations in property law. A trust is a relationship whereby property is held by one party for the benefit of another. A trust is created by a settlor (the person who creates the trust), who transfers some or all of his or her property to a trustee (a person either an individual, a corporation or more than one of either who administers a trust). The trustee holds that property for the trust's beneficiaries (a beneficiary is anyone who receives benefits from any assets the trust owns). Personal trust law developed in England at the time of the Crusades, during the 12th and 13th centuries. The trust relationship was created by later common law jurisdictions. Trusts play a significant role in most common law systems, and their success has led some civil law jurisdictions to incorporate trusts into their civil codes. In this article we will discuss trust's treatment as a relationship in the common law system, his characteristics and development.We will analyse the trust's treatment relationship in the civil law system, the differences and things in common between these two systems.
\end{abstract}

\section{Introduction}

Trusts have existed since Roman times and have become one of the most important innovations in property law. The concept of trust is derived by the terms of "testamentary trusts" created by wills. Trusts were a creation of the English law of property and obligations, but also share a history with countries across the Commonwealth and the United States. Trusts developed when claimants in property disputes were dissatisfied with the common law courts and petitioned the King for a just and equitable result. Personal trust law developed in England at the time of the Crusades, during the 12th and 13th centuries.

In medieval English trust law, the settlor was known as the feoffor to uses while the trustee was known as the feoffee to uses and the beneficiary was known as the cestui que use, or cestui que trust.In some countries trust relationship is treated while in other countries it is not developed as relationship. However this institution is not only a "local" institution treated only by Common Law system, but is also developed by Civil Law system and mixed $^{1}$ system. A trust is a relationship whereby property is held by one party for the benefit of another. Trust is a legal relationship created on the basis of trust that exists between the founders of this relationship

\footnotetext{
${ }^{1}$ Such as Scotland and South Africa
} 
(trustor) and the trustee. The trustor realizes the transfer, inter vivos or mortis causa, of property or of his rights in favor of trustee. Trust can be considered even as a hybrid between contract and property. The trustor has the right of the trust's administration as if he was the owner. But this thing is realized in the benefit of the beneficiary or the achievement of a certain purpose.It can happen to have trust where is not determined the final beneficiary. In the Continental Europe there are similar institutions with trust such as dutch institution fiducia cum amico or fideicommissum, fiducia and treuhand and even the legal institution of german right, bewind. Trust can even be compared with the contract in favor of a third person that is treated by the Albanian Civil Code and with the will. Trust with both these institutions has things in common and differences. In this article it will be analyzed trust institution, its treatment according common law and its treatment according civil law.

\section{Trust and Its Main Elements}

Property of any sort may be held in a trust. The uses of trusts are many and varied, for both personal and commercial reasons. The main objective of creating a trust is that the fruits derived from its administration will be transferred to the benificiary. Then after reaching a certain age or over a specified time or the completion of a certain condition the property's ownership will be transferred in a full way to the benificiary. Two elements that characterize trust's institution are : a) transfer of a certain property; b) administration of that property for the benefit of beneficiary. The parties that participate in this relationship are: 1) Settlor (trustor)- this is the person who creates the trust by giving real or personal property in trust to a trustee for the benefit of a beneficiary and who gives such property is said to settle it on the trustee.

A trustee- a person (either an individual, a corporation or more than one of either) who administers a trust. A trust may have multiple trustees, and these trustees are the legal owners of the trust's property, but have a fiduciary duty to beneficiaries and various duties, such as a duty of care and a duty to inform ${ }^{2}$.

A trustee is considered a fiduciary and owes the highest duty under the law to protect trust assets from unreasonable loss for the trust's beneficiaries. The trustee does not have the right of a full ownership as at the end of the trust he is obliged to transfer this property to the beneficiary.

A beneficiary- is a person that is not part in the relationship initially established by the two abovementioned parties, but is the direct interested as he is the person that either immediately or eventually, will receive income from the trust property, or will receive the property itself.A beneficiary can be an individual, a corporation or some persons that may not exist at the moment of trust' s creation. The extent of a beneficiary's interest depends on the wording of the trust document. One beneficiary may be entitled to income, whereas another may be entitled to the entirety of the trust property when he attains the age of twenty-five years. The settlor has much discretion when creating the trust, subject to some limitations imposed by law. Trust's institution can find the biggest use in practice on issues as: a) Trust for disabled persons- through which it is possible the administration of the goods of different categories ${ }^{3}$ in favor of a disabled person. Trust in this case is seen as more favorable compared with other forms of trusteeship as it leaves little opportunity for autonomous administration by disabled persons; b) Trust for the familyserves to discipline cases of inheritance, kinship relationships, marital crises, including divorce cases; c) Trust for joint ownership ${ }^{4}$ - through which is realized the objective of trasnfer of

2 Edward Jones Trust Company. Fundamental Duties of a Trustee: A Guide for Trustees in a postUniform Trust Code World

3 These include movable property or immovable money till to insurance policies

${ }^{4}$ We can speak about joint ownership in case of partnership or in the case of other forms of commercial companies 
ownership in a simple way from how predict the relevant provisions in relation to it. Trust creates larger facilities on the allocation of assets of companies, in protecting its assets or shares. In some cases this can be accompanied with fiscal advantages ${ }^{5}$, but always in respect of the relevant legal provisions; d) Trust for purposes of guarantee- Part of the trust can be movable property or immovable even money.It can happen to create a separate asset and administered for the realization of a certain purpose for which it is required guarantee. The person in favor of which is given this guarantee can enjoy a fortune, which can not be "hit" with any kind of indictment.Trust in this case allows the administration and pledge or mortgage of the property that is the subject of guarantee benefiting the advantages.

Generally, a trust requires three certainties :

1. Intention. There must be a clear intention to create a trust.

2. Subject Matter. The property subject to the trust must be clearly identified .Trust property may be any form of specific property, be it real or personal, tangible or intangible. It is often, for example, real estate, shares or cash.

3. Objects. The beneficiaries of the trust must be clearly identified, or at least be ascertainable.In the case of discretionary trusts, where the trustees have power to decide who the beneficiaries will be, the settlor must have described a clear class of beneficiaries.

Beneficiaries may include people not born at the date of the trust (for example, "my future grandchildren"). Alternatively, the object of a trust could be a charitable purpose rather than specific beneficiaries.

\subsection{Purposes of trust}

Among the main purposes for which a trust is created are:

1. Privacy: Trusts may be created purely for privacy. The terms of a will are public and the terms of a trust are not.

2. Child custody and of disabled persons: The thing that is noticed in testamentary provisions is that minors have a limited right to use literally estate until they have reached a certain age. The same thing happens to disabled persons.

3. Estate planning: In this case the trust is created to administer the estate received through inheritance by creating a protective tool against its abuse by persons unable to administer.

4. Charities: In some common law jurisdictions all charities must take the form of trusts.

5. Pension plans: Pension plans are typically set up as a trust, with the employer as settlor, and the employees and their dependents as beneficiaries.

6. Asset protection:Trusts may allow beneficiaries to protect assets from creditors as the trust may be bankruptcy remote.

7. Advantages of fiscal natures: As a result of the trust's creation may come many fiscal advantages. Trust provides that the owner of a particular asset may renounce of it, passing the administration to a third person.In this case as it can not be known with certainty who receives the fruits of this administration is impossible that property taxation.

8. Money laundering: It happens that the trust' s institution is used even for purposes not quite right as money laundering obtained from the different crimes.

This is an illegal purpose and this crime is prosecuted.However there is a decrease in the number of cases in which the trust is used for this purpose, especially among limited company, capital societies etc.

For a long time has been accepted by many researchers that trust is a typical Common Law institution. The claim is that trust is a unique english-american institution and continental legal

\footnotetext{
5 In the sense of saving money
} 
tradition has not developed it. ${ }^{6}$ In Albania, trust is not recognized as institution. In the case when a trust is valid to another country that recognizes it and the estate is there too the Albanian judge has to consider it as institution.It is very similar to trust of common law in the continental right the so-called substitution fidekomisar that is a testament commandments through which the testator charges the heir or legatee to save the estate or a several object transferring them to a third person after the death of such heir or legatee.The Albanian Civil Code of 1929 expressly forbade this institution, while the current Civil Code does not recognize it ${ }^{7}$.

In Italy trusts can be used thanks to the adoption of the Hague Convention (1 July 1985), executive from 1 January 1992. The "trust interno" is a domestic trust but refers to a foreign regulation because as of August 2010 Italy does not have a complete and organic internal regulation on trust. Trusts can be used for various aims 8 : administration, transfer of family business assets, transfer of goods for charity purposes, protection of patrimony, etc.The italian right recognizes in a limit way this institution (article 692 of the Italian Civil Code) recognizing as valid only those commandments according to which after the child's death, descendants or spouse, the estate passes to their children. Signs of implementation of procedures similar to those being pursued by the trust, show that there is a close connection between the English trust and institution such as fideicomissum, fiducia and treuhand, which are present in continental legal tradition. Thus there is a common connection that joins these two major legal families in this regard ${ }^{9}$. Trust is present in mixed jurisdictions such as those of Scotland or South Africa if the following elements are present: a) Trustee must act in good faith in the sense that besides other duties, trustee must act with loyalty and for the benefit of the beneficiary of trust; b) must happen a division of the personal assets of the trustee and the assets that are part of trust; c) shall be subject to the trust the benefits obtained from the use of assets that are part of it; d) creation of a trust's relationship as an institution. For Maurizio Lupoi, a more right definition of trust in terms of the comparative right should include the following elements: a) Transfer of assets to the trustee or making of a universal declaration in relation with it;

b) Lack of "conflict of interest" among property that is part of trust and personal property of trustee ${ }^{10}$;

c) lack of any kind of power over property that is part of trust by his trustor;

d) The existence of a specific purpose for which the trust is created;

e) The duty of trustee to act in good faith at the time of exercising his rights. ${ }^{11}$

The main influence of England was felt in the nineteenth century and more later from the time when trust already constituted an important institution of the scottish right. With regard to South Africa trust that was introduced by british colonists in the nineteenth century, was the trust that really existed in England ${ }^{12}$. Indeed, South African trusts do not involve a strict separation as exists in English law, relying instead on a duality of estates. The Scottish trust, which is deeply influenced by civil law, recognises the beneficiaries' interest as a personal right and not a property right. Furthermore, it is clear that the relationship between equity and trusts is a product of

${ }^{6}$ John H. Langbein, "The Contractorian Basis of Trust" 1995, 105 Yale LJ 625, 669

7 Av. Agim I Tartari Trashëgimia në të drejtën ndërkombëtare private shqiptare, Botim 2010, fq.134

8 Edoardo Andreoli, Trust and company law-The italian experience (pp 7-23) in "Estates, taxes and professional ethics: papers of the International Academy" by Rosalind Atherton, Kluwer Law International,2003-Business \& Economics

9 Richard Helmholz and Reinhard Zimmermann, "Views of Trust and Treuhand:An introduction", in Helmholz and Zimmermann 27,30

10 This corresponds to the second element of the first classification

11 This corresponds to the fistr element of the first classification

12 Tony Honore, "Trust", in Rinhard Zimmermann and Daniel Visser, Southern Cross: Civil Law and Common Law in South Africa 1996,849,850 
England's unique history, and is but one way of achieving a segregation and protection of the trust assets ${ }^{13}$. The French Civil Code does not know the institution of trust. It can safely be said that this is no longer the case of French taxation law, which, as of July 2011, provides a definition of the trust. This does not allow trusts to be created in French law but allows foreign trusts to be recognised as such, and thereafter taxed, where a territorial link is established. In February 2007, the French Parliament introduced, under Chapter 14 of the Civil Code, the fiducie. This tailormade legal institution, draws upon the Roman law concept of fiducia and the experience of analogue institutions from other civil law jurisdictions such as Luxembourg, but also from the common law trust ${ }^{14}$. Liechtenstein is the country of Europe, which has had the fullest development of trust institution. However similar institution with trust are found in the right germanic and that dutch.In Netherlands the institution that is more similar to trust inter vivos is fiducia cum amico.In this case happens that assets are transferred to a manager (fiduciarius), that has to manage them in the benefit of one or more beneficiaries. However unlike the beneficiary of the trust in common law, beneficiary in this case does not have real rights on these assets. Another legal institution in the Dutch right is bewind.Even in this institution the bewindvoerder manages assets on benefit of beneficiaries.In this case, unlike the trustee, the bewindvoerder does not own the assets.

Ownership here is of the beneficiary. In other words the bewindvoerder acts as the agent's beneficiary.Another similar institution with trust in the dutch right is the institution of stichting, but unlike the trust, stichting in this case can only be a corporate. In the Germanic right ${ }^{15}$ the testator may determine in the will that his estate will pass to a person in the qualityr of "provisional successors" (Vorebe) and then with death or with the fulfillment of a specific condition from this person the property will pass to the "the subsequent successors "(Nacherbe) .But the testator reserves the right not to include" the temporary heir "(Vorerbe) and instead of his te transfer the estate to a testamentary executor (testamentsvollstrecker). This latter has the responsibility to administer the property in accordance with the testator's instructions. This system of passing the estate is similar to the trust in common law. The germanic institution that is more similar to the trust is Treuhand.In this case the executor (Treuyhander) undertakes to administer the inheritance property in benefit of beneficiary. The difference between Treuyhander in this case and the trustee is that the trustee acquires ownership of that property and furthermore it must keep separate his personal property from property acquired through trust. These elements are not present to Treuhand.

\section{Conclusions}

Trusts have existed since Roman times and have become one of the most important innovations in property law. A trust is a relationship whereby property is held by one party for the benefit of another. Trusts were a creation of the English law of property and obligations, but we can find also in the Continental Europe similar institutions with trust such as dutch institution fiducia cum amico or fideicommissum, fiducia and treuhand and even the legal institution of german right, bewind. The Albanian Civil Code does not recognize the trust's institution. In Italy

13 Hiroyuki Watanabe, “Trusts without Equity" and Prospects for the Introduction of Trusts into European Civil Law Systems' 196; De Waal MJ, 'In Search of a Model for the Introduction of the Trust into a Civilian Context'; (2001) 12 Stellenbosch Law Review 66.

14 Yaell Emerich, 'The Conceptual Foundations of France's Fiducie Faced with the Trust of the Common Law: Between the Law of Contract and Property Law (Les Fondements Conceptuels de La Fiducie Française Face au Trust de La Common Law: Entre Droit Des Contrats et Droit Des Biens)' [2009] 1 Revue Internationale de Droit Comparé 50; Bénédicte François, Fiducie (Dalloz 2011) 5

${ }^{15}$ Hein Kotz "National Report for Germany", Hayton et.al 85 
trusts can be used thanks to the adoption of the Hague Convention (1 July 1985), executive from 1 January 1992. and trusts can be used for various aims: administration, transfer of family business assets, transfer of goods for charity purposes, protection of patrimony, etc. Trusts can not be created in French law but foreign trusts are recognised as such, and thereafter taxed, where a territorial link is established. Liechtenstein is the country of Europe, which has had the fullest development of trust institution. Trust is present too in mixed jurisdictions such as those of Scotland or South Africa.

\section{References}

Edward Jones Trust Company. Fundamental Duties of a Trustee: A Guide for Trustees in a post-Uniform Trust Code World

John H. Langbein, "The Contractorian Basis of Trust” 1995, 105 Yale LJ 625, 669

Av. Agim I Tartari Trashëgimia në të drejtën ndërkombëtare private shqiptare, Botim 2010

Edoardo Andreoli, Trust and company law-The italian experience (pp 7-23) in "Estates, taxes and professional ethics:papers of the International Academy" by Rosalind Atherton, Kluwer Law International, 2003-Business \& Economics

Richard Helmholz and Reinhard Zimmermann, "Views of Trust and Treuhand:An introduction", in Helmholz and Zimmermann 27,30

Tony Honore, "Trust", in Rinhard Zimmermann and Daniel Visser, Southern Cross: Civil Law and Common Law in South Africa 1996,849,850

Hiroyuki Watanabe, "Trusts without Equity" and Prospects for the Introduction of Trusts into European Civil Law Systems' 196; De Waal MJ, 'In Search of a Model for the Introduction of the Trust into a Civilian Context'; (2001) 12 Stellenbosch Law Review 66.

Yaell Emerich, 'The Conceptual Foundations of France's Fiducie Faced with the Trust of the Common Law: Between the Law of Contract and Property Law (Les Fondements Conceptuels de La Fiducie Française Face au Trust de La Common Law: Entre Droit Des Contrats et Droit Des Biens)' [2009] 1 Revue Internationale de Droit Comparé 50; Bénédicte François, Fiducie (Dalloz 2011) 5

Hein Kotz "National Report for Germany", Hayton

Loi n²007-211 du 19 février 2007 instituant la fiducie". Legifrance.gouv.fr, le service public de la diffusion du droit. 1 February 2009.

Scott, Austin. "Importance of the Trust". U. Colo. L. Rev. Retrieved 6 April 2014. The greatest and most distinctive achievement performed by Englishmen in the field of jurisprudence is the development from century to century of the trust idea. 